\title{
LABORATORY TESTING OF STEEL FIBER CONCRETE PRISM FOR TENSION IN BENDING
}

\author{
${ }^{1}$ Surianinov M.G., Doctor of Science, Professor, \\ sng@ogasa.org.ua, ORCID: 0000-0003-2592-5221 \\ ${ }^{1}$ Neutov S.P., PhD, Assistant Professor, \\ neutov.stepan@gmail.com, ORCID: 0000-0002-0132-124X \\ ${ }^{1}$ Korneeva I.B., PhD, Assistant Professor, \\ korneevairinaborisovna@gmail.com, ORCID: 0000-0002-0104-6938 \\ ${ }^{1}$ Kalchev I.K., Student, \\ kalchevigor00@gmail.com, ORCID: 0000-0003-4293-1930 \\ ${ }^{1}$ Odesa State Academy of Civil Engineering and Architecture \\ Didrikhsona str., 4, Odesa, 65029, Ukraine
}

\begin{abstract}
Laboratory bending tests of concrete and steel-fiber-concrete prisms were carried out. The concrete matrix for all prisms is made of a concrete mixture of the same composition with a coarse aggregate size up to $10 \mathrm{~mm}$ and a water-cement ratio that allows correct mixing of the ready mixture with fiber, so that the latter is evenly distributed over the sample volume. Fiber reinforcement is $1 \%$ for all three types of fiber, a fiber made of the same steel with an ultimate strength of $1335 \mathrm{MPa}$, fiber length $50 \mathrm{~mm}$, diameter $1 \mathrm{~mm}$ is used. Fibers differ only in shape, which makes it possible to compare test results across series without correction factors. Concrete samples without fiber are considered as control samples.

As a result of laboratory tests, data sets were obtained and analyzed, which are presented in the form of diagrams. Different types of steel fiber show different increases in the load at the beginning of cracking and load-bearing capacity. The most profitable from this point of view is the addition of anchor fiber to concrete, the least - wave fiber. However, the presence of any of the considered steel fibers in the mixture significantly increases the load-bearing capacity of the sample. In addition, the type of destruction of such a sample changes from brittle to viscous.

We also studied the deformability of samples with different fiber reinforcement and plotted the dependence of the relative longitudinal strain on the load. Before the crack formation begins, there is a direct proportionality between the load and the strain with the appearance of cracks, the slope of the graphs changes sharply. When the load-bearing capacity is lost, steel fiber-reinforced concrete samples are restrained from final destruction.

The use of steel fiber in concrete on average increases the crack resistance by $40 \%$, and the loadbearing capacity by $64 \%$. Compared with samples without fiber reinforcement, samples with anchor fiber show an increase in load-bearing capacity by $89 \%$, and crack resistance by $61 \%$. When using flattened fiber, these values are $56 \%$ and $32 \%$, and for wave fiber $-47 \%$ and $25 \%$, respectively. The use of steel fiber in the manufacture of concrete mix avoids the brittle nature of destruction.
\end{abstract}

Keywords: steel fiber concrete, laboratory testing, prism, steel fiber, flexural tensile testing.

Introduction. Today, concrete remains the most popular material in the construction industry. Unfortunately, for all its positive qualities, it is quite easily susceptible to fragile destruction. The use of fiber allows you to change the nature of the destruction process. Unlike conventional concrete, in which this process occurs almost instantly, there is no brittle destruction in fiber concrete, and the sample continues to resist the load, and the nature of the destruction changes from brittle to viscous.

Recent researches analysis. In foreign countries, fiber reinforcement has long been used to increase the viscosity of the concrete mix. In [1], the influence of various reinforcing elements on the strength characteristics of fiber concrete was studied. The influence of fiber parameters, including material, fiber shape, and the percentage of fiber reinforcement on compressive, axial, 
and flexural strength is considered. It was concluded that it is optimal to use steel fiber with curved ends, as well as a mixture of polymer and steel fibers in a certain ratio, which allows you to increase the class of the material for compression and bending.

In [2], the behavior of samples with different fiber reinforcement of concrete under load is also considered and a recommendation is given to use steel fibers to increase the bending strength in those reinforced concrete structures in which the control of concrete cracking is particularly important.

The influence of the optimal percentage of steel fiber on the bending behavior of beams was studied in the article [3]. Tests have shown that $1 \%$ volume reinforcement with fiber with curved ends with a diameter of $0.75 \mathrm{~mm}$ and $50 \mathrm{~mm}$ long allows you to increase the load before the first crack appears, as well as the bending strength.

In the study [4], the main attention is paid to the influence of fibers on the mechanical properties of steel fiber - compressive strength, tensile strength under axial loading, and tensile strength under bending. The results show a significant increase in tensile strength and bending strength for fiber reinforced concrete with anchor fiber; the resulting load-strain diagrams are presented and summary recommendations are given.

As shown by experimental data [5], the best bending characteristics are found in samples reinforced with steel fiber. In this work, three types of fibers (polymer, glass, and steel) were used in a special concrete matrix with three different volume fractions: 2,4 , and $6 \%$. The results of the bending and stretching tests were compared with each other to find a correlation between the two tests.

Interesting tests were conducted by the authors [6]. This research was mainly focused on the influence of the type and shape of steel fibers on the mechanical properties of concrete, with particular attention paid to the issue of maximizing the strength of steel fiber. For this purpose, in order to avoid pulling the fiber out of the concrete during loading, a geometrically closed form of the fiber is proposed instead of a linear one.

Domestic and foreign authors are engaged in research on this issue [7-14], but there is still not enough statistical data in this area for the reason that tensile tests during bending are carried out using similar, but still different loading schemes, which complicates the comparison of results. Therefore, laboratory tensile tests for bending prisms made of steel fiber are relevant.

The purpose of this work is a laboratory study of the effect of the type of steel fiber on the strength and deformative properties of steel fiber concrete.

Materials and methods. A series of $100 \times 100 \times 400$ prism samples are made of $\mathrm{C} 20 / 25$ concrete according to [15]. The zero series consists of concrete samples from a mixture of optimal composition [16], the first, second, and third series contain fibers of different steel fibers (Fig. 1).

a)

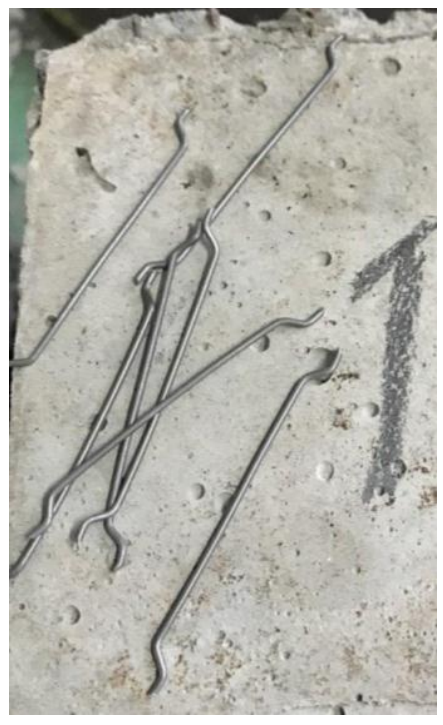

b)

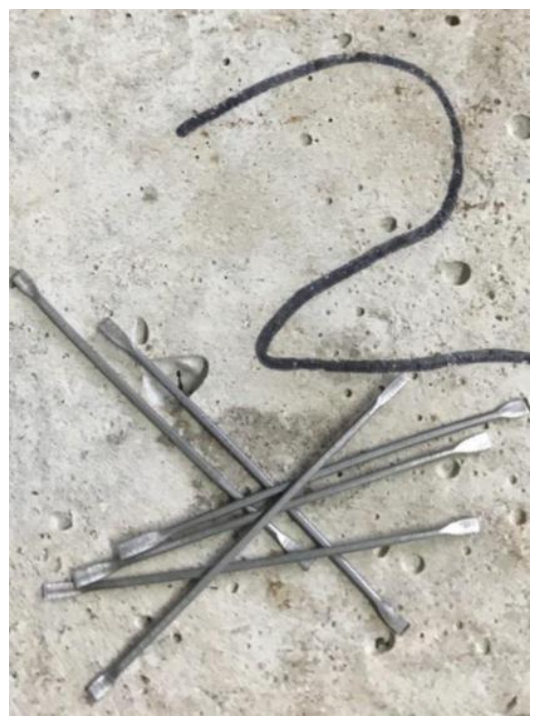

c)

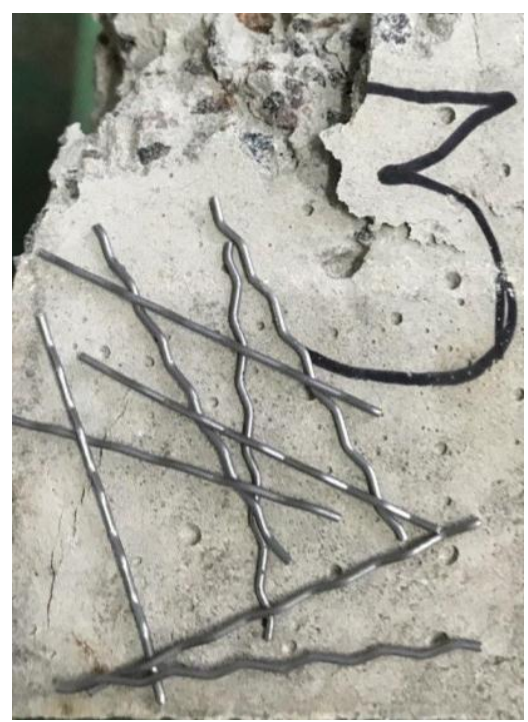

Fig. 1. Types of steel fiber used:

$\mathrm{a}$ - anchor; $\mathrm{b}$ - flattened; $\mathrm{c}$ - wave 
The tests were carried out according to the scheme shown in Fig. 2. To measure deformations on the samples, hour-type indicators were fixed with a base of $20 \mathrm{~cm}$ on one side surface and with a base of $10 \mathrm{~cm}$ on the other in the zone of pure bending. The vertical load was applied using a jack, its value was determined by a dynamometer.

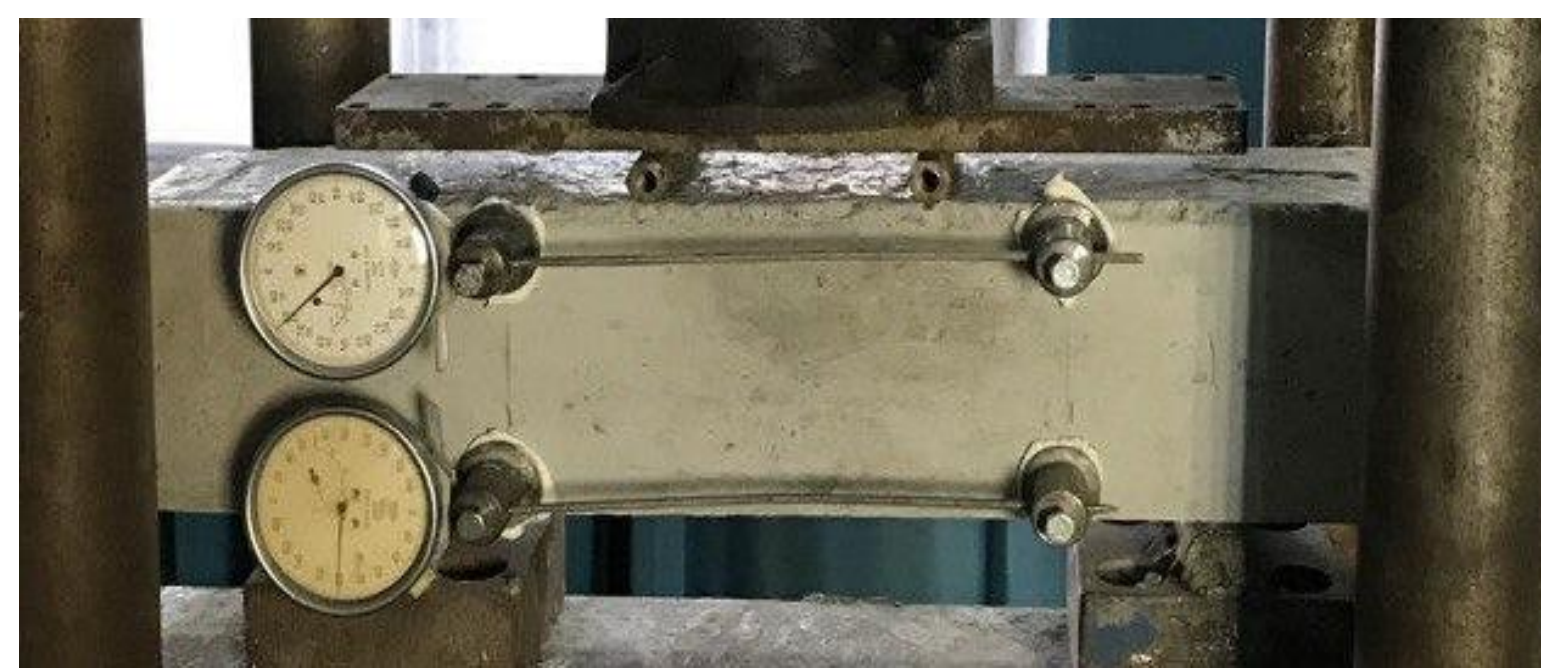

Fig. 2. Test scheme

During the tests, the load, deformation of the sample, as well as the moment of the beginning of crack formation were recorded. For samples with fiber, the parameters of cracks, their height and width of opening were measured.

Research results. Laboratory tests of concrete and steel fiber-reinforced concrete prisms for bending were carried out. The concrete matrix for all prisms is made of a concrete mixture of the same composition with a large aggregate size of up to $10 \mathrm{~mm}$ and a water-cement ratio that allows correct mixing of the finished mixture with fiber for its uniform distribution over the sample volume. Fiber reinforcement is $1 \%$ for all three types of fiber, using fiber made of the same steel with a temporary resistance of $1335 \mathrm{MPa}$, fiber length of $50 \mathrm{~mm}$, diameter of $1 \mathrm{~mm}$. Fibers differ only in their shape, which allows you to compare test results by series without correcting coefficients. Concrete samples without fiber are considered as control samples.

As a result of laboratory tests, data sets were obtained and analyzed, which are more clearly presented in the form of diagrams.

Thus, Fig. 3 and Fig. 4 show that different types of fiber show different increases in the load at the beginning of crack formation and load-bearing capacity, although the trend for the series remains. The most profitable from this point of view is the addition of anchor fiber to concrete, the least - wave fiber. However, the presence of any of the considered steel fibers in the mixture significantly increases the load-bearing capacity of the sample. In addition, the type of fracture such a specimen changes from brittle to viscous, that is, if the control concrete prisms the beginning of cracking load and breaking load is the same value, for fiber-reinforced concrete load-bearing capacity from the load at the beginning of cracking is characterized by $17-18 \%$, regardless of the form of fiber. 


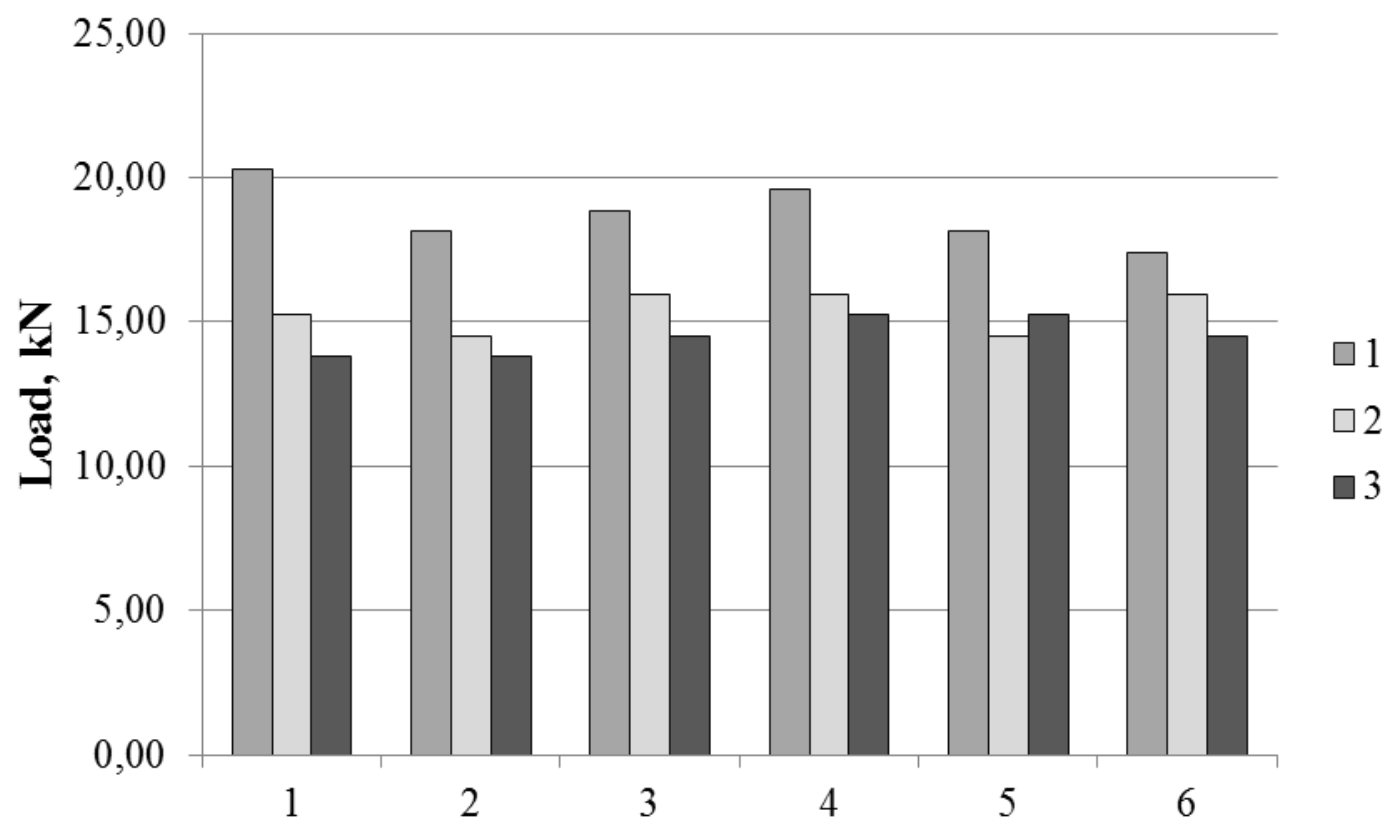

Fig. 3. Load corresponding to the beginning of crack formation of samples in series depending on the type of fiber:

1 - anchor; 2 - flattened; 3 - wave

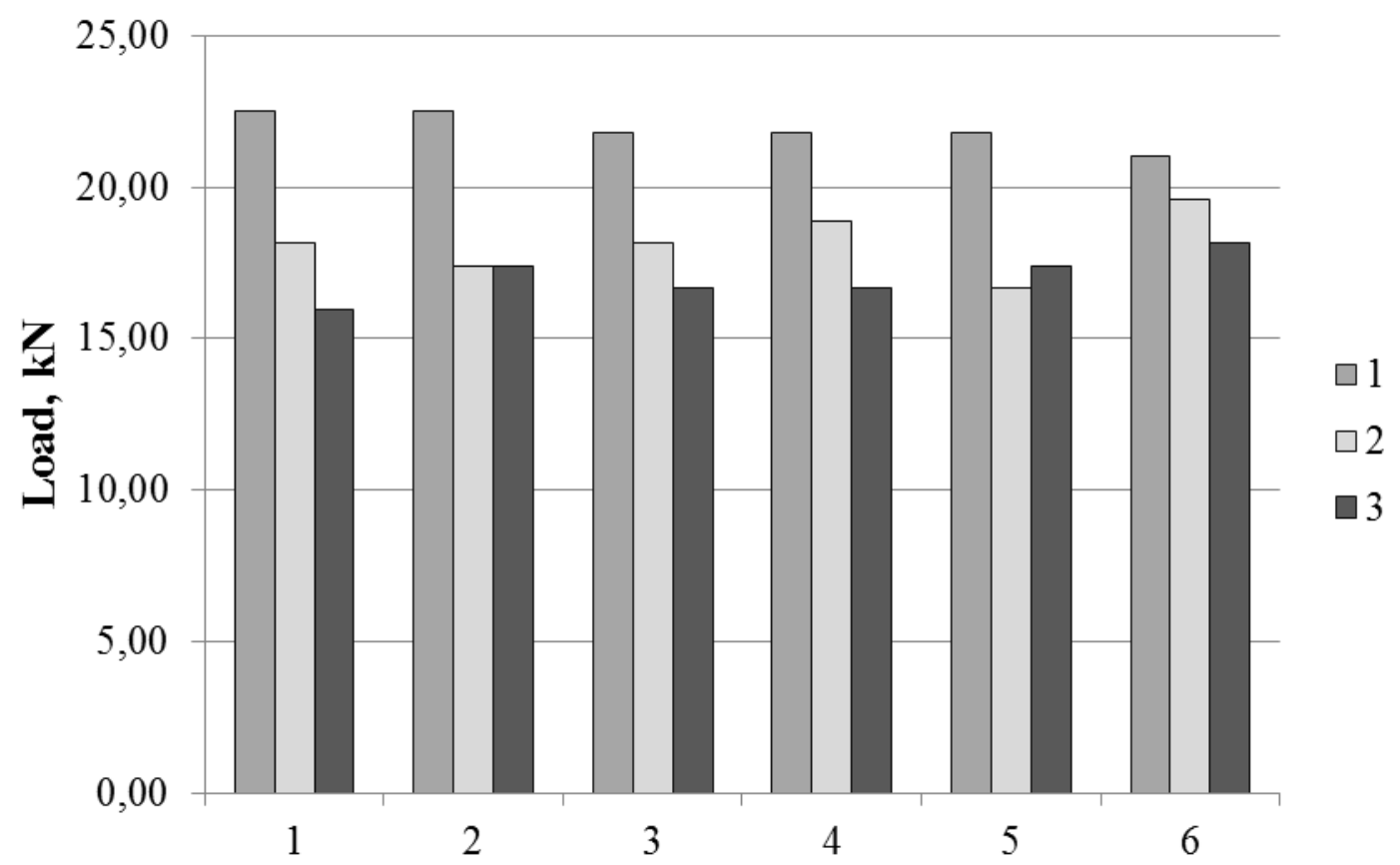

Fig. 4. Load-bearing capacity of samples by series depending on the type of fiber: 1 - anchor; 2 - flattened; 3 - wave

If you compare different types of fiber with each other, the advantage of the first option becomes obvious. From this we can conclude that it is advisable to use anchor steel fiber in structures.

Any fiber reinforcement from the considered ones has a positive effect on the strength characteristics of concrete. Figure 5 shows the average values for a series of samples with fiber in comparison with zero reinforcement. The use of steel fiber on average increases the load of the beginning of cracking by $40 \%$, and the load-bearing capacity - by $64 \%$. 


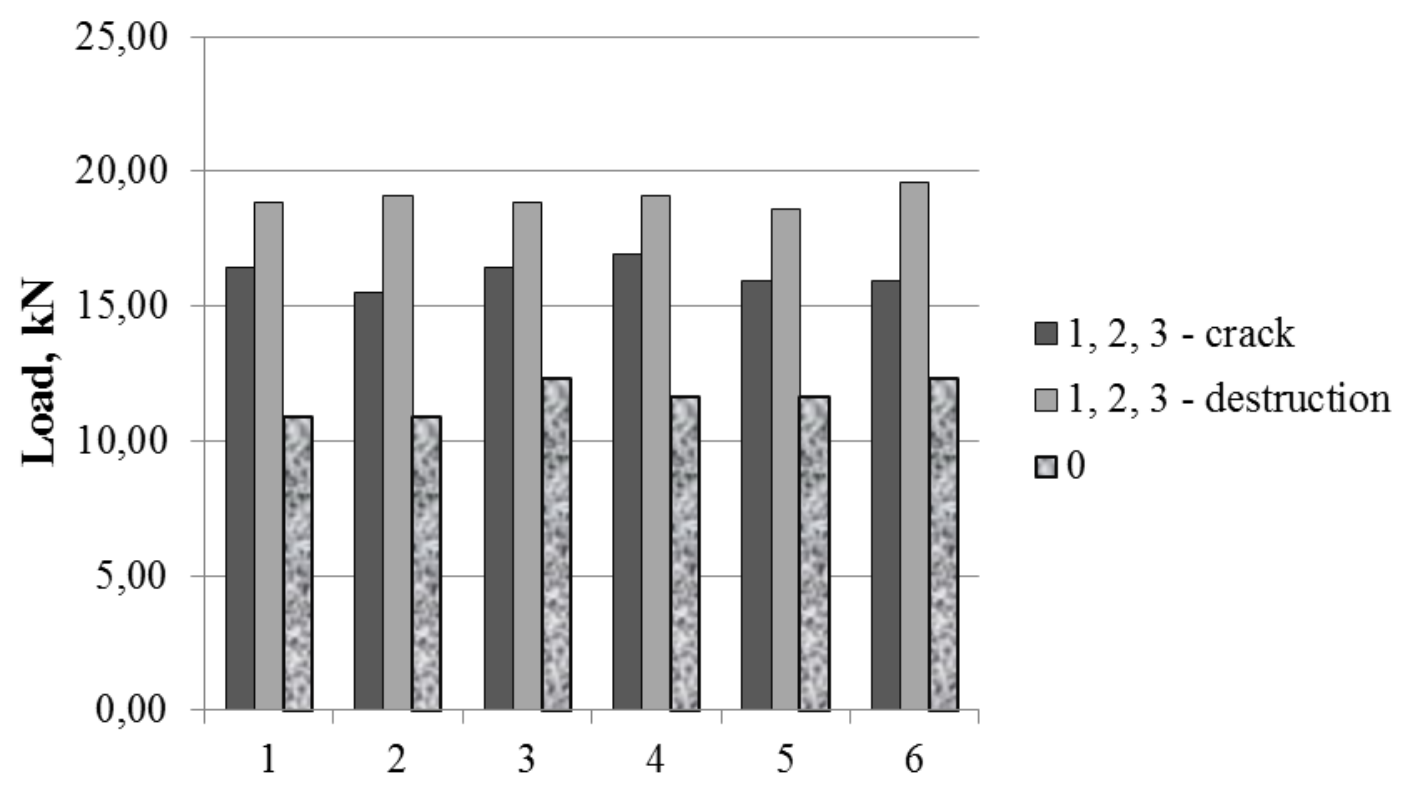

Fig. 5. Load corresponding to the beginning of crack formation and loss of load-bearing capacity of samples in series, depending on the presence of fiber

The same analysis was performed separately for the types of fiber (Fig. 6). Relative to a series of samples without fiber reinforcement, samples with anchor fiber show an increase in load bearing capacity by $89 \%$, and crack resistance by $61 \%$. When using flattened fiber, these values are $56 \%$ and $32 \%$, and for wave fiber $-47 \%$ and $25 \%$.

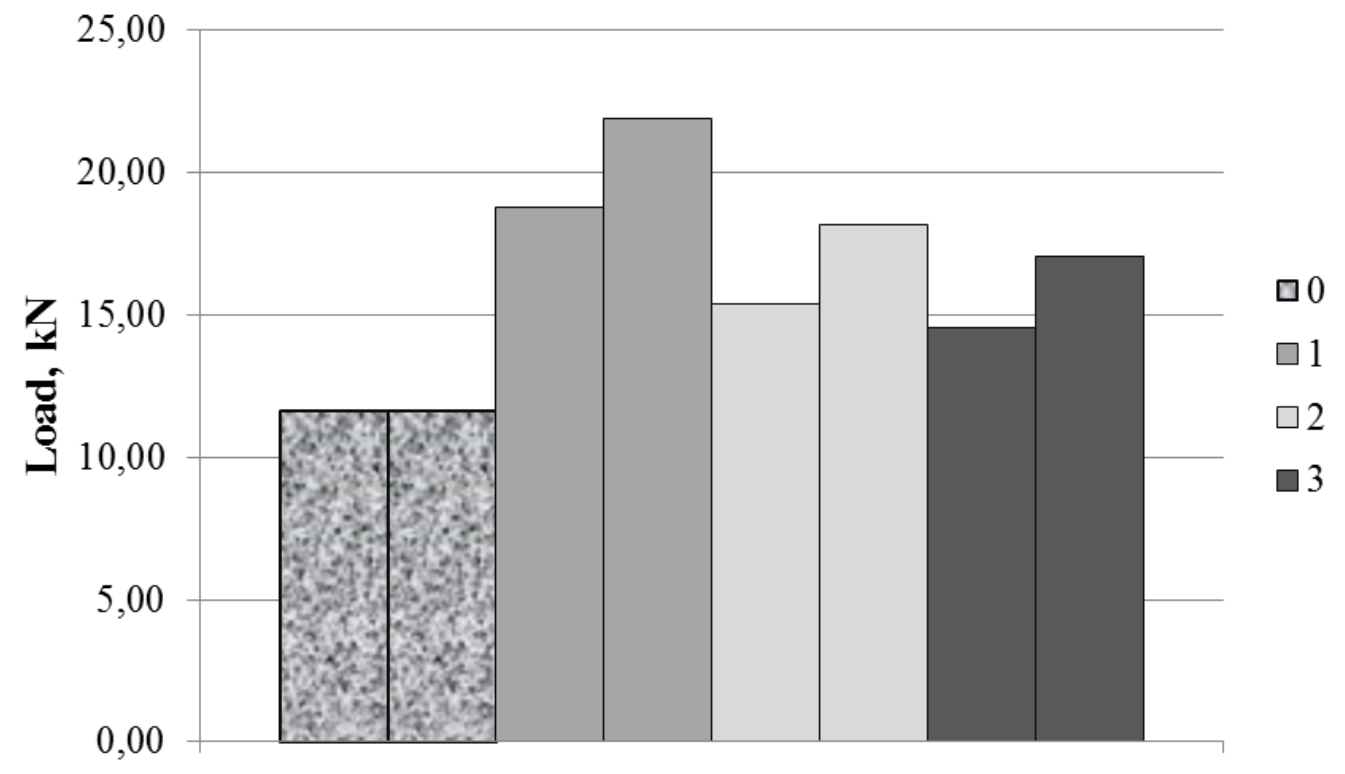

Fig. 6. Load corresponding to the beginning of crack formation and loss of bearing capacity of samples depending on the presence and type of fiber:

0 - concrete sample without fiber; 1 - anchor; 2 - flattened; 3 - wave

Also studied the deformability of specimens with different fiber reinforcement and plots of relative longitudinal strain from the load (Fig. 7). Prior to the beginning of cracking there is a direct proportionality between load and deformation with cracking the slope of the graphs changes dramatically, but reinforced with steel fiber samples are not destroyed. When the load increases, cracks open, and the deformation increases up to the loss of load-bearing capacity. 


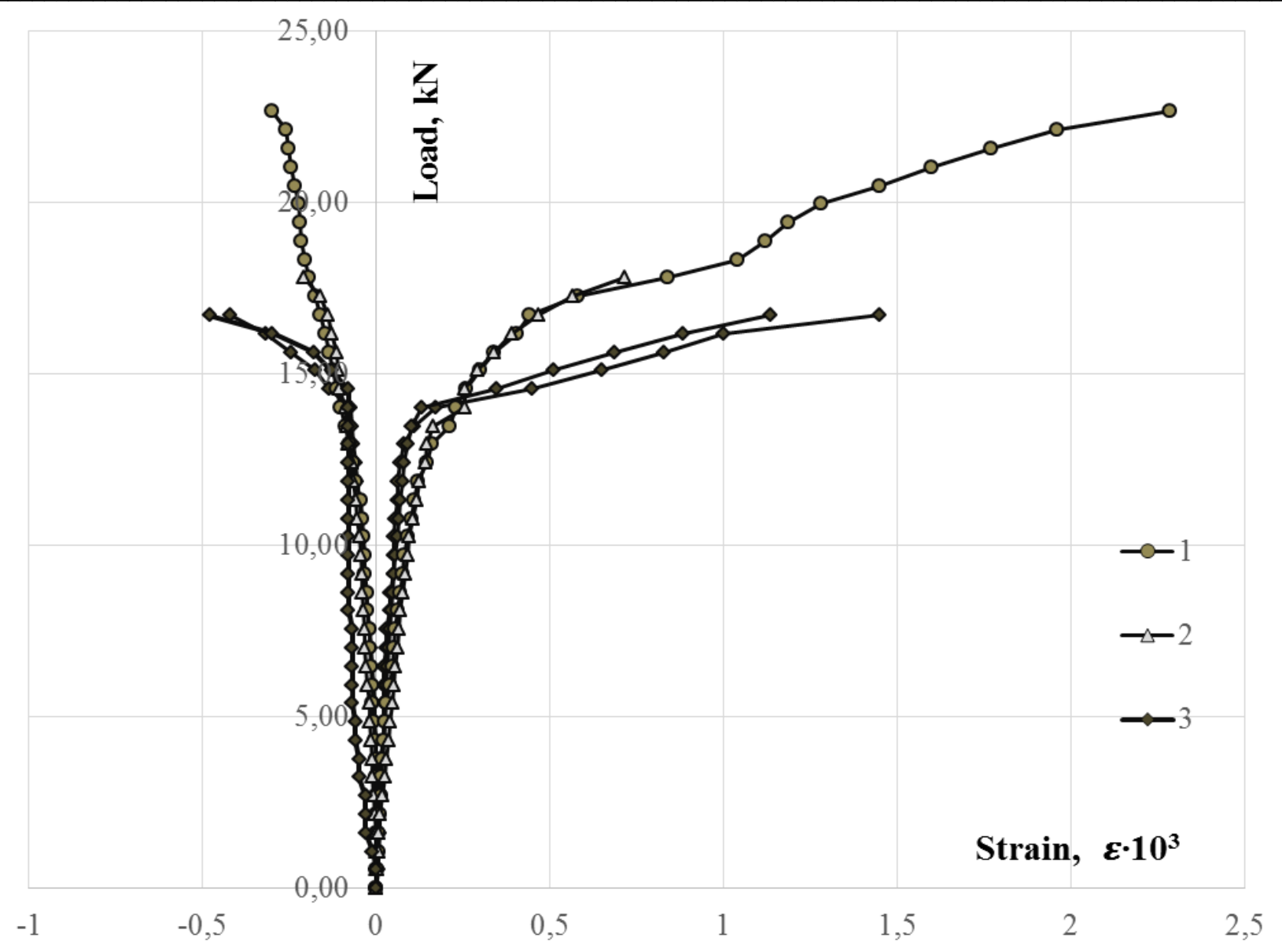

Fig. 7. Relative deformation of samples depending on the type of fiber:

1 - anchor; 2 - flattened; 3 - wave

But even if the load-bearing capacity is lost, steel-fiber concrete samples, unlike concrete ones, do not break up into two parts, and each remains a single whole, since it is kept from final destruction by fibers, as can be seen in Fig. 8 .

a)

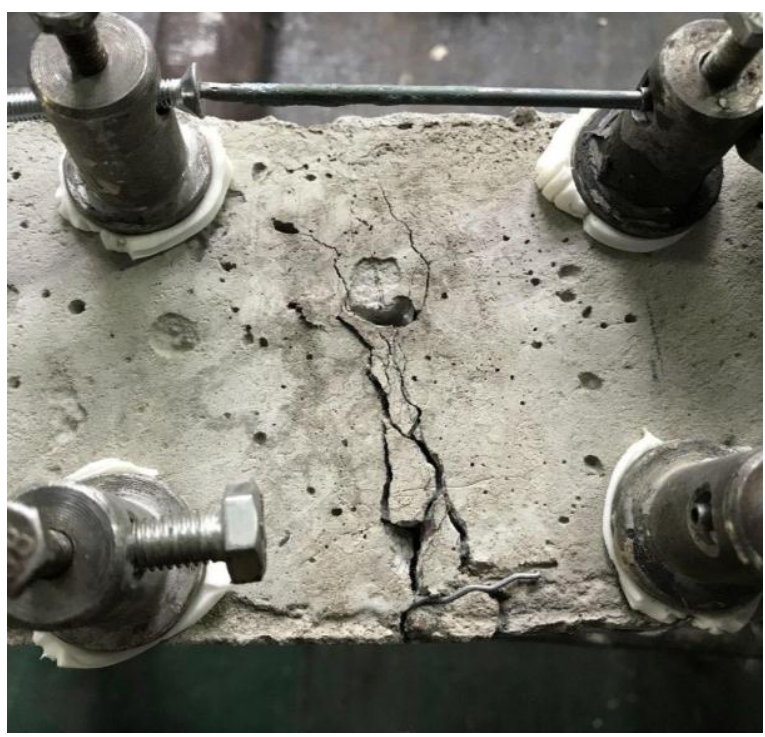

b)

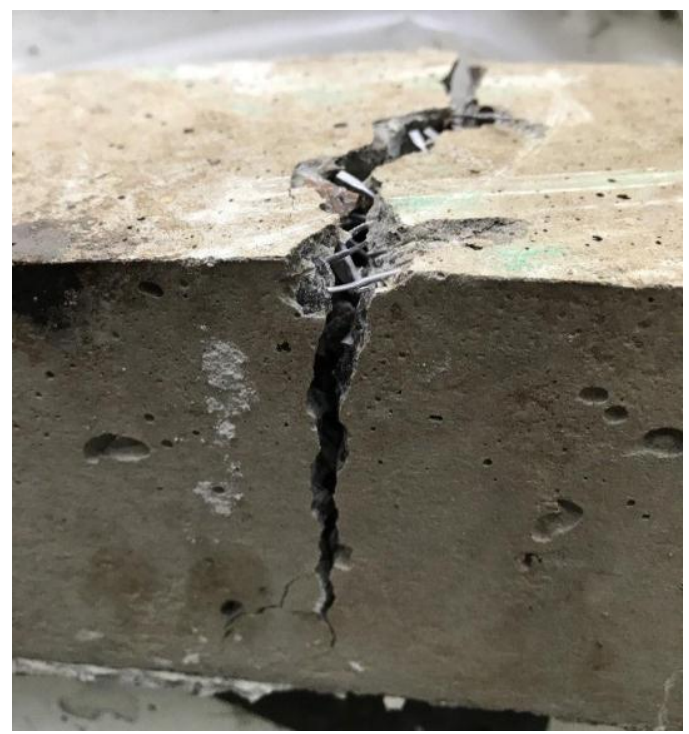

Figure 8. Fiber-Reinforced concrete samples after loss of load-bearing capacity: $a$ - in the zone of pure bending; $b$ - view of the sample from below 
Conclusions. The use of steel fiber in concrete on average increases the crack resistance by $40 \%$, and the load-bearing capacity by $64 \%$. Compared with samples without fiber reinforcement, samples with anchor fiber show an increase in load - bearing capacity by $89 \%$, and crack resistance by $61 \%$. When using flattened fiber, these values are $56 \%$ and $32 \%$, and for wave fiber $-47 \%$ and $25 \%$, respectively. The use of steel fiber in the manufacture of concrete mix avoids the brittle nature of destruction.

\section{References}

[1] Reza Babaie, Milad Abolfazli, Ahmad Fahimifar, Mechanical properties of steel and polymer fiber reinforced concrete, De Gruyter, 2019, pp. 119-133.

[2] N. Buratti, C. Mazzotti, M. Savoia, "Experimental study on the flexural behaviour of fibre reinforced concretes strengthened with steel and macro-synthetic fibres", Structural engineering, Korea Concrete Institute, University of Bologna, pp. 1286-1294, 2010.

[3] Hamid Pesaran Behbahani, Behzad Nematollahi, Abdul Rahman Mohd. Sam, F.C. Lai, "Flexural behavior of steel-fiber-added-rc (sfarc) beams with c30 and c50 classes of concrete", International Journal of Sustainable Construction Engineering \& Technology, vol. 3, Issue 1, pp. 54-63, 2012.

[4] Zuzana Marcalikova, Radim Cajka, Vlastimil Bilek, David Bujdos, Oldrich Sucharda, "Determination of Mechanical Characteristics for Fiber-Reinforced Concrete with Straight and Hooked Fibers", Department of Structures, Faculty of Civil Engineering, VSB-Technical University of Ostrava, Department of Building Materials and Diagnostics of Structures, Faculty of Civil Engineering, VSB-Technical University of Ostrava, 2020, pp. 1-19.

[5] Mehmet Kemal Ardoğa, Emin Şengün, Burhan Alam, İsmail Özgür Yaman, "Determination of the tensile strength of different fiber reinforced concrete mixtures", Civil Engineering Department, Middle East Technical University, Ankara, Turkey, pp. 1-8, 2016.

[6] Shahid Iqbal, Ihsan Ali, Shah Room, Shaukat Ali Khan, Ahsan Ali, Enhanced mechanical properties of fiber reinforced concrete using closed steel fibers, 2019, pp. 1-9.

[7] D.S. Zaharov, "Analiz faktorov vliyayuschih na prochnost pri izgibe betnov transportnogo naznacheniya", Vestnik Harkovskiy natsionalnyiy avtomobilno-dorozhnyiy universitet, vol. 79, pp. 151-157, 2017.

[8] M.G. Holodnyak, M.P. Nazhuev, A.V. Zaretskiy, Yu.S. Fominyih, N.A. Dotsenko, "Zavisimost prochnosti na rastyazhenie pri izgibe tsentrifugirovannogo betona ot fibrovogo armirovaniya dispersnyimi voloknami razlichnyih vidov", Vestnik Evraziyskoy nauki, no. 3, pp. 1-9, 2019.

[9] Luca Sorelli, Alberto Meda, A. Giovanni, "Plizzari Bending and Uniaxial Tensile Tests on Concrete Reinforced with Hybrid Steel Fibers", Journal of materials in civil engineering (C) asce, pp. 519-526, 2005.

[10] Mohd Ahmed, Javed Mallick, Mohd, Abul Hasan, "A study of factors affecting the flexural tensile strength of concrete", Journal of King Saud University. Engineering Sciences, vol. 28, Issue 2, pp. 147-156, 2016.

[11] Yuanxun Zheng, Xiaolong Wu, Guangxian He, Qingfang Shang, Jianguo Xu, Yikai Sun, "Mechanical Properties of Steel-Fiber Reinforced Concrete by Vibratory Mixing Techology", Advances in Civil Engineering, vol. 2018, Article ID 9025715, 2018.

[12] Won-Chang Choi, Kwon-Young Jung, Seok-Joon Jang, Hyun-Do Yun, "The Influence of Steel Fiber Tensile Strengths and Aspect Ratios on the Fracture Properties of HighStrength Concrete", Department of Architectural Engineering, Gachon University, Department of Architectural Engineering, 2019, pp. 1-10.

[13] Hao Zhou, Bin Jia, Hui Huang and Yanling Mou, "Experimental Study on Basic Mechanical Properties of Basalt Fiber Reinforced Concrete", Department of Civil Engineering and Architecture, Southwest University of Science and Technology, 2020, pp. 1-19. 
[14] J. Carrillo, J. Cárdenas Pulido, W. Aperador, "Flexural mechanical properties of steel fiber reinforced concrete under corrosive environments", Revista Ingeniería de Construcción, vol. 32, no. 2, pp. 59-71, 2017.

[15] DSTU B.V.2.7-214:2009. Betony. Metody vyznachennya mitsnosti za kontrol'nymy zrazkamy. K.: Minrehionbud Ukrayiny, 2010.

[16] S.F. Neutov, A.A. Boyadzhi, I.B.Korneeva, "Opredelenie osnovnyih fizikomehanicheskih harakteristik stalefibrobetonnoy smesi optimalnogo sostava", World science, no. 5 (33), vol. 2, p. 26-30, 2018.

\title{
ЛАБОРАТОРНІ ВИПРОБУВАННЯ ПРИЗМ ІЗ СТАЛЕФІБРОБЕТОНУ НА РОЗТЯГУВАННЯ ПРИ ЗГИНІ
}

\author{
${ }^{1}$ Сур'янінов М.Г., д.Т.н., професор, \\ sng@ogasa.org.ua, ORCID: 0000-0003-2592-5221 \\ ${ }^{1}$ Неутов С.П., к.Т.н., доцент, \\ neutov.stepan@gmail.com, ORCID: 0000-0002-0132-124X \\ ${ }^{1}$ Корнеєва I.Б., К.Т.Н., доцент, \\ korneevairinaborisovna@gmail.com, ORCID: 0000-0002-0104-6938 \\ ${ }^{1}$ Кальчев І.К., студент, \\ kalchevigor00@gmail.com, ORCID: 0000-0003-4293-1930 \\ ${ }_{1}^{1}$ Одеська державна академія будівниитва та архітектури \\ вул. Дідріхсона, 4, м. Одеса, 65029, Україна
}

\begin{abstract}
Анотація. Проведено лабораторні випробування бетонних і сталефібробетонних призм на згин. Бетонна матриця для всіх призм виконана з бетонної суміші однакового складу з розміром крупного заповнювача до 10 мм і водоцементним відношенням, що дозволяє коректне перемішування готової суміші з фіброю, щоб остання була рівномірно розподілена по об'єму зразка. Фіброве армування складає 1\% для всіх трьох видів фібри, використовується фібра 3 однакової сталі з тимчасовим опором 1335 МПа, довжиною волокна 50 мм, діаметром 1 мм. Відрізняються фіброві волокна тільки формою, що дозволяє порівнювати результати випробувань за серіями без коригувальних коефіцієнтів. Бетонні зразки без фібри розглядаються як контрольні.
\end{abstract}

В результаті лабораторних випробувань були отримані і проаналізовані масиви даних, які представлені у вигляді діаграм. Різного виду сталева фібра показує неоднакове підвищення навантаження початку тріщиноутворення і несучої здатності. Найбільш вигідним з цієї точки зору виявляється додавання в бетон анкерної фібри, найменш - хвильової. Але присутність у складі суміші будь-якої з розглянутих сталевих фібр значно підвищує несучу здатність зразка. Крім того, тип руйнування такого зразка змінюється з крихкого на в'язкий.

Також була вивчена деформативність зразків 3 різним фібровим армуванням i побудовані графіки залежності відносної поздовжньої деформації від навантаження. До початку тріщиноутворення спостерігається пряма пропорційність між навантаженням і деформацією, з появою тріщин нахил графіків різко змінюється. При втраті несучої здатності сталефібробетоні зразки від остаточного руйнування стримують фіброві волокна.

Застосування сталевої фібри в складі бетону в середньому підвищує тріщиностійкість на 40\%, а несучу здатність на 64\%. У порівнянні зі зразками без фібрового армування, зразки 3 анкерною фіброю показують підвищення несучої здатності на $89 \%$, а тріщиностійкості на $61 \%$. При використанні плющеної фібри ці значення становлять 56\% і 32\%, а для хвильової 47\% і 25\% відповідно. Використання сталевої фібри при виготовленні бетонної суміші дозволяє уникнути крихкого характеру руйнування.

Ключові слова: сталефібробетон, лабораторні випробування, призма, сталева фібра, випробування на розтяг при згині. 


\title{
ЛАБОРАТОРНЫЕ ИСПЫТАНИЯ ПРИЗМ ИЗ СТАЛЕФИБРОБЕТОНА НА РАСТЯЖЕНИЕ ПРИ ИЗГИБЕ
}

\author{
${ }^{1}$ Сурьянинов Н.Г., д.т.н., профессор, \\ sng@ogasa.org.ua, ORCID: 0000-0003-2592-5221 \\ ${ }^{1}$ Неутов С.Ф., к.т.н., доцент, \\ neutov.stepan@gmail.com, ORCID: 0000-0002-0132-124X \\ ${ }^{1}$ Корнеева И.Б., к.т.н., доцент, \\ korneevairinaborisovna@gmail.com, ORCID: 0000-0002-0104-6938 \\ ${ }^{1}$ Кальчев И.К., студент, \\ kalchevigor00@gmail.com, ORCID: 0000-0003-4293-1930 \\ ${ }^{1}$ Одесская государственная академия строительства и архитектуры \\ ул. Дидрихсона, 4, г. Одесса, 65029, Украина
}

\begin{abstract}
Аннотация. Проведены лабораторные испытания бетонных и сталефибробетонных призм на изгиб. Бетонная матрица для всех призм выполнена из бетонной смеси одинакового состава с размером крупного заполнителя до 10 мм и водоцементным отношением, позволяющим корректное перемешивание готовой смеси с фиброй, чтобы последняя была равномерно распределена по объему образца. Фибровое армирование составляет $1 \%$ для всех трех видов фибры, используется фибра из одинаковой стали с временным сопротивлением $1335 \mathrm{MПа,} \mathrm{длиной} \mathrm{волокна} 50$ мм, диаметром 1 мм. Отличаются фибровые волокна только формой, что позволяет сравнивать результаты испытаний по сериям без корректирующих коэффициентов. Бетонные образцы без фибры рассматриваются как контрольные.

В результате лабораторных испытаний были получены и проанализированы массивы данных, которые представлены в виде диаграмм. Разного вида стальная фибра показывает неодинаковое повышение нагрузки начала трещинообразования и несущей способности. Наиболее выгодным с этой точки зрения оказывается добавление в бетон анкерной фибры, наименее - волновой. Но присутствие в составе смеси любой из рассмотренных стальных фибр значительно повышает несущую способность образца. Кроме того, тип разрушения такого образца меняется с хрупкого на вязкий.

Также была изучена деформативность образцов с разным фибровым армированием и построены графики зависимости относительной продольной деформации от нагрузки. До начала трещинообразования наблюдается прямая пропорциональность между нагрузкой и деформацией, с появлением трещин наклон графиков резко изменяется. При потере несущей способности сталефибробетонные образцы от окончательного разрушения сдерживают фибровые волокна.

Применение стальной фибры в составе бетона в среднем повышает трещиностойкость на $40 \%$, а несущую способность на $64 \%$. По сравнению с образцами без фибрового армирования, образцы с анкерной фиброй показывают повышение несущей способности на $89 \%$, а трещиностойкости на $61 \%$. При использовании плющеной фибры эти значения составляют 56\% и $32 \%$, а для волновой - 47\% и $25 \%$ соответственно. Использование стальной фибры при изготовлении бетонной смеси позволяет избежать хрупкого характера разрушения.
\end{abstract}

Ключевые слова: сталефибробетон, лабораторные испытания, призма, стальная фибра, испытания на растяжение при изгибе.

Стаття надійшла до редакції 12.10.2020 